\title{
A Bronze Medal for Switzerland at the 40th International Chemistry Olympiad 2008 in Budapest
}

\author{
Manuel Fragnière and Karin Birbaum ${ }^{\star}$
}

\begin{abstract}
At the 2008 International Chemistry Olympiad in Budapest, with 65 participating countries, a Swiss student won a bronze medal.
\end{abstract}

Keywords: ICHO $\cdot$ International Chemistry Olympiad $\cdot$ Swiss students

In 2008, the International Chemistry Olympiad celebrated its 40th anniversary in Hungary, one of the three countries that founded the Chemistry Olympiad in 1968. It took place from 12th to 21st July 2008 in Budapest. The program was rich and varied, with visits and magnificent excursions. Furthermore, the organization was optimal for all jury sessions, translations and arbitration sessions and for the checking of the material of the practical exam.

The students were hosted in Gödöllö, a scenic city northeast of Budapest. The mentors were hosted on Margrit Island, between Buda and Pest, in a four-star hotel with swimming pool and sauna.

The theoretical and practical exams took place in the Eötvös Loránd Technical University (ELTE). The jury sessions and the translations were organized in the Margrit Island hotel. The questions were so clearly presented that they were adopted in a minimum amount of time: two hours for the practical problems and three hours for the theoretical problems. Last

${ }^{\star}$ Correspondence: K. Birbaum

ETH Zurich

Department of Chemistry and Applied Biosciences Laboratory of Inorganic Chemistry

$\mathrm{HCl} \mathrm{G141}$

Wolfgang-Pauli-Strasse 10

$\mathrm{CH}-8093$ Zurich

Tel: +41446334523

Fax: +41446331071

E-Mail: birbaum@inorg.chem.ethz.ch

www.swisscho.ch

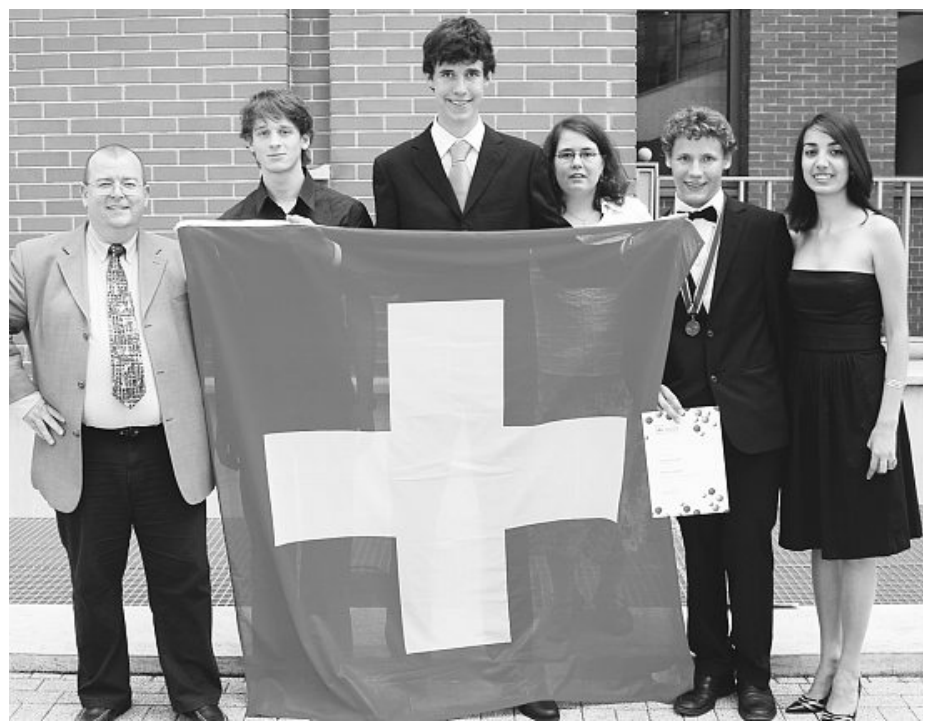

Fig. 1. From left to right: Manuel Fragnière (Mentor, Lycée Denisde-Rougemont, Neuchâtel), Matthias Rüdt (Winterthur), Mario S. Könz (Müstair), Karin Birbaum (Head Mentor, Baar), Andreas Frutiger (Bronze medal, Hilterfingen), Nina Zargari (Belmont)

year in Moscow these discussions lasted three times longer.

65 countries were present in Budapest, each one with four candidates. The four Swiss candidates were:

- Andreas Frutiger, Gymnasium Thun Schadau, Hilterfingen BE (bronze medal);

- Mario S. Könz, Lyceum Alpinum Zuoz, Müstair GR;

- Matthias Rüdt, Kantonsschule Büelrain Winterthur, Winterthur ZH;

- Nina Zargari, Gymnase de Chamblandes Lausanne, Belmont-Lausanne VD.

The Swiss mentors were:

- Karin Birbaum, head mentor, ETH Zurich, Baar ZG;

- Manuel Fragnière, mentor, Lycée Denis-de-Rougemont, Neuchâtel NE.

The three practical problems were an organic synthesis ( $\alpha$-D-glucopyranose pentaacetate), a titration of zinc by hexacyanoferrate(II)) and a cation-anion cross-determination with eight unknown salt solutions, with no other reagent but pH-paper.

The nine theoretical problems were related to acid-base equilibrium (problem 1), organic chemistry (problems 2,3 and 4), precipitation reactions (problem 5), clathrate chemistry and crystallography (problem 6), dithionate ion $\left(\mathrm{S}_{2} \mathrm{O}_{6}{ }^{2-}\right)$ synthesis coupled with a spectrophotometric titration (problem 7), lanthanide(III) complexes (problem 8 ) and thallium triiodide complexes (problem 9). The problems were very difficult, but could be solved by well-trained secondary school students. Two problems are detailed at the end of this article.

A case of proved cheating darkened the last session of the jury. The mentors 
of Tadjikistan inserted the answers into their Tadjik version of the problems. The discussion was intense about which penalty to adopt. After a lot of considerations, an agreement was found for two types of penalties: a ban for the country Tadjikistan to participate in the next Olympiad, and a definitive exclusion for the cheating team (students and mentors).

The grading scheme was the following:

- Honourable Citation: from 39.0 to 40.7 pts.

- Bronze Medal: from 40.7 to 56.0 pts.

- Silver Medal: from 56.0 to 66.6 pts.

- Gold Medal: from 66.6 to 100 pts.

The three top candidates came from China, Singapore and Russia. The best one, the Chinese Yougping $\mathrm{Fu}$, obtained 87.0 points out of 100. The best European was Stefan Pusch, from Germany with 75.7 points (gold medal). The best Swiss, Andreas Frutiger, obtained a bronze medal, with 53.0 points.

The next Olympiads will be held in Cambridge (2009), Tokyo (2010), Turkey (2011) and USA (2012). Further candidates are Singapore, Vietnam and Thailand.

The Swiss team thanks all its supporters, especially the KGF (Kontaktgruppe für Forschung) and the SBW (Staatssekretariat für Bildung und Wissenschaft).

And at the end, here are two problems to test your chemical knowledge:

\section{Example 1 \\ (Problem 2 of the $40^{\text {th }}$ IChO)}

Determine the structure of the compounds $\mathbf{A}-\mathbf{H}$ (stereochemistry is not expected), based on the information given in the Scheme.

\section{Hints:}

A is a well-known aromatic hydrocarbon. A hexane solution of $\mathbf{C}$ reacts with sodium (gas evolution can be observed), but $\mathbf{C}$ does not react with chromic acid.

${ }^{13} \mathrm{C}$ NMR spectroscopy shows that $\mathbf{D}$ and $\mathbf{E}$ contain only two kinds of $\mathrm{CH}_{2}$ groups.

When a solution of $\mathbf{E}$ is heated with sodium carbonate an unstable intermediate forms at first, which gives $\mathbf{F}$ on dehydration.

Answers: The answers are given in Fig. 2 .

\section{Example 2 (Problem 6 of the $40^{\text {th }}$ IChO)}

A feathery, greenish solid precipitate can be observed if chlorine gas is bubbled into water close to its freezing point. Similar precipitates form with other gases such as methane and noble gases. These materials are interesting because vast quantities of the so-called methane hydrates are supposed to exist in nature (comparable in quantity with other natural gas deposits).

These precipitates all have related structures. The molecules of water just above its freezing point form a hydrogenbonded structure. The gas molecules stabilize this framework by filling in the rather large cavities in the water structure forming clathrates.

The crystals of chlorine and methane clathrates have the same structure. Their main characteristics are dodecahedra formed from 20 water molecules. The unit cell of the crystal can be thought as a body-centered cubic arrangement built from these dodecahedra which are almost spherical objects. The dodecahedra are connected via additional water molecules located on the faces of the unit cell. Two water molecules can be found on each face of the unit cell. The unit cell has an edge dimension of $1.182 \mathrm{~nm}$.

There are two types of cavities in this structure. One is the internal space in the dodecahedra (A). These are somewhat smaller than the other type of voids $(\mathbf{B})$, of which there are six for each unit cell.

a) How many type A cavities can be found in a unit cell?

b) How many water molecules are there in a unit cell?

c) If all cavities contain a guest molecule, what is the ratio of the number of water to the number of guest molecules?

d) Methane hydrate is formed with the structure in c) at temperatures between $0-10{ }^{\circ} \mathrm{C}$. What is the density of the clathrate?

e) The density of chlorine hydrate is $\mathbf{1 . 2 6}$ $\mathrm{g} / \mathrm{cm}^{3}$. What is the ratio of the number of water and guest molecules in the crystal?

Which cavities are likely to be filled in a perfect chlorine hydrate crystal? Mark one or more.
Covalent radii reflect atomic distances when the atoms are covalently bonded. Nonbonded or van der Waals radii give a measure of the atomic size when they are not bonded covalently (modeled as hard spheres).

Table.

\begin{tabular}{lll} 
Atom & $\begin{array}{l}\text { Covalent } \\
\text { radius [pm] }\end{array}$ & $\begin{array}{l}\text { Nonbonded } \\
\text { radius [pm] }\end{array}$ \\
\hline H & 37 & 120 \\
C & 77 & 185 \\
O & 73 & 140 \\
$\mathrm{Cl}$ & 99 & 180
\end{tabular}

f) Based on the covalent and nonbonded radii of these atoms estimate lower and upper bounds for the average radii of the cavities where possible. Show your reasoning.

Let us consider the following processes

$\mathrm{H}_{2} \mathrm{O}(\mathrm{l}) \rightarrow \mathrm{H}_{2} \mathrm{O}(\mathrm{s})$

$x \mathrm{CH}_{4}(\mathrm{~g})+\mathrm{H}_{2} \mathrm{O}(\mathrm{l}) \rightarrow$

$\mathrm{xCH}_{4} \cdot 1 \mathrm{H}_{2} \mathrm{O}$ (clathrate)

g) What are the signs of the following molar quantities referring to these reactions in the given direction at $4{ }^{\circ} \mathrm{C}$ ? Mark with $\mathrm{a}-, 0$ or $+: \Delta G_{\mathrm{m}}(1), \Delta G_{\mathrm{m}}(2), \Delta H_{\mathrm{m}}(1)$, $\Delta H_{\mathrm{m}}(2), \Delta S_{\mathrm{m}}(1), \Delta S_{\mathrm{m}}(2), \Delta S_{\mathrm{m}}(2)-$ $\Delta S_{\mathrm{m}}(1), \Delta H_{\mathrm{m}}(2)-\Delta H_{\mathrm{m}}(1)$.

Answers:

a) 2

b) $46=20 \times 2($ dodecahedra $)+6 \times 2 / 2$ (faces)

c) $46: 8=5.75$

d) The density is $1.589 / 1.651=$ $0.962 \mathrm{~g} / \mathrm{cm}^{3}$

e) 6 (5.98) chlorine molecules for the 46 waters, or a ratio of 7.68

Some B (only the 6 larger B type cavities contain chlorine)

f) $234 \mathrm{pm}<r(\mathrm{~A})<279 \mathrm{pm}$ and $279 \mathrm{pm}<$ $r(\mathrm{~B})$

g),,,,,,,+-------

The other problems can be found at http://www.icho.hu/pages/problems.aspx.

The original exams in German and French can be found on: www.icho.ch

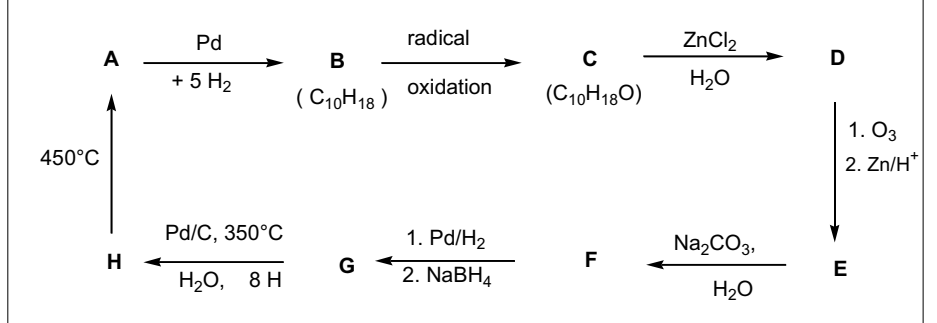

Scheme. Reaction Scheme for example 1

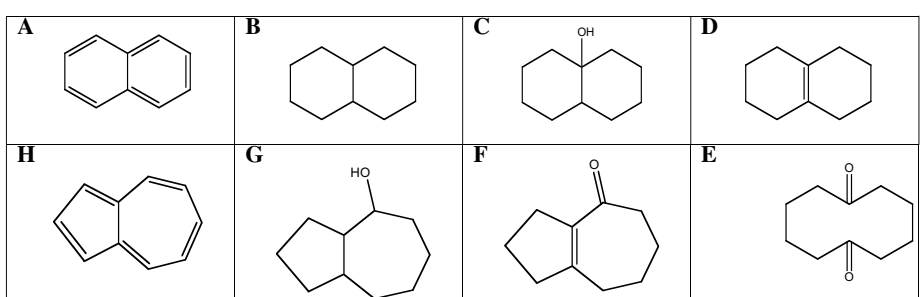

Fig. 2. Answer to example 1 